\title{
Biomechanics of Neck Injuries Resulting from Rear-End Vehicle Collisions
}

\section{Otomobil Kazalarnda Boyun Yaralanmaları Biyomekaniği}

\section{Deniz U. ERBULUT}

Koc University, School of Medicine, Departments of Mechanical Engineering and Neurosurgery, Istanbul, Turkey

Corresponding Author: Deniz U. ERBULUT / E-mail: erbulut.deniz@gmail.com,derbulut@ku.edu.tr

\begin{abstract}
It has been claimed that $85 \%$ of the neck injuries caused by car accidents are the result of rear-end collisions. This type of injury is called a whiplash injury, and its mechanisms are not completely understood due to the limited ability to diagnose them using X-ray or MRI. Biomechanical studies including research on injury mechanisms, injury criteria, neck kinematics and injury epidemiology were reviewed to investigate the details of whiplash injuries. Many different injury mechanisms has been studied and identified such as hyperextension of the neck, facet joint impingement, spine column pressure, and muscle strains. Possible injury criterions have been reported as The Neck Injury Criterion (NIC), Nij criterion, IV-NIC criterio, Nkm criterion, NDC criterion.
\end{abstract}

KEYWORDS: Cervical spine, Whiplash injury, Rear-end collision, Neck injury mechanism

\section{öz}

Yapılan araştırmalar sonucunda, araba kazalarında meydana gelen boyun yaralanmalarının $\% 85^{\prime} i$ arkadan çarpmalar sonucunda meydana geldiği bilinmektedir. Bu tür boyun yaralanmalarına "whiplash" ya da kırbaç yaralanmaları adı verilmektedir. Bu tür yaralanmalar yumuşak doku yaralanmalarıdır ve bilinen X-ray ve MRI teknikleri yaralanmanın teşhis edilmesi için yeterli gelmediğinden, mekanizması tam olarak anlaşılmış değildir. Biyomekanik çalışmalar, örneğin yaralanma mekanizması ve kriterleri, boyun kinematiği, yaralanma epidemiyolojisi vs. bu tür boyun yaralanma mekanizmasının anlaşııması için yapılmaktadır. Birçok boyun yaralanma mekanizması çalışılmış ve raporlanmıştır. Bu mekanizmalar boynun çok fazla ekstensiyon yapması, kaslardaki stresler, omuriliğin baskı görmesi, faset eklemlerde meydana gelen kayma stresleridir. Muhtemel boyun yaralanma kriterlerin bazıları ise The Neck Injury Criterion (NIC), Nij criterion, IV-NIC criterio, Nkm criterion, NDC criterion olarak tanımlanmıştır.

ANAHTAR SÖZCÜKLER: Servikal omurga, Kamçı yaralanması, Arkadan çarpma, Boyun yaralanma mekanizması

\section{INTRODUCTION}

Fifty percent of cervical injuries in car accidents occur as the result of rear-end collisions (5). These injuries, which are also called "whiplash injuries," are conceptualized as small-scale injuries causing problems such as long-term neck pain and limitation of movement. Whiplash injuries occur in the neck as a result of momentary flexion and extension movements of the cervical spine. Whiplash injuries, which can be seen even in low-speed, rear-end collisions, are generally dangerous for the driver and the passenger in the front seat. The mechanisms of whiplash injuries are not fully understood. One of the reasons for this lack of understanding is that this sort of injury is difficult to diagnose using methods such as basic radiography and MRI (Magnetic Resonance Imaging). Whiplash injuries that are the result of rear-end collisions cause complaints such as neck pain, stiffness in the neck, sensory impairments, etc. The costs of medical services for these types of injuries offer information about the global rate of whiplash injuries. Richter et al. (17) stated that 10 billion euros has been spent on cervical injuries resulting from rearend collisions in Europe alone.
The science of biomechanics uses acceleratory and kinematical information pertaining to the head and neck in low-speed, rear-end collisions for analyzing whiplash injuries. We can say that the acceleration of the head and the neck increases towards the direction of the rear-end collision, and the neck extends during the accident. We can define the velocity change of the vehicle during the accident as delta- $V$ $(\Delta \mathrm{V})$. Although the velocity change is very small $(8-16 \mathrm{~km} / \mathrm{h})$, a high value of acceleration $(a=\Delta / \Delta \mathrm{t})$ can be observed for the very small time period $(\Delta \mathrm{t})$ of the velocity change. As seen in several studies, $8 \mathrm{~km} / \mathrm{h}$ is the threshold value for whiplash injuries caused by rear-end collisions. Whiplash injuries start with the speed value of $8 \mathrm{~km} / \mathrm{h}$, and their severity increases accordingly as the level of speed increases. Additionally, it is known that the acceleration of the body of the passenger is quite different from the acceleration of the car. In an experiment performed with human subjects by Siegmund et al. (19), the acceleration of the head was observed to be almost two times greater than the acceleration of the car (Figure 1). Figure 1 shows that $\mathrm{T} 1$ and the head accelerate, in that order, following the acceleration of the car. 
According to statistical data, the speed of the impact, the headrest of the seat, the position of the passenger, the material of the seat and the design of the seat all affect the intensity of whiplash injuries. In a study conducted by Kraft et al. (9), whiplash injuries were found to be unavoidable in rear-end accidents that generated at least $7 \mathrm{~g}$ acceleration. It was also observed that there was no risk of whiplash injuries in accidents with $3 \mathrm{~g}$ acceleration. The severity of injuries may vary according to not only the acceleration caused by the collision but also the mechanical structure of the car. For instance, in one experiment, it was hypothesized that a car that normally presented minimal risk of whiplash to the passenger presented increased risk when the same car was articulated. The position of the passenger is another factor: a passenger in the front seat has a greater risk of whiplash injuries than does a passenger in the back seat (7).

Another important factor is the seat's headrest. Much biomechanical research has been conducted to understand the effects of headrests on whiplash injuries. Attempts have been made to prevent and restrain the backwards movement of the neck in rear-end accidents. Lubin et al. (11) reported that the headrests of most of the 992 cars investigated were not adjusted as they should have been. According to the report, the headrests that could be adjusted were in the wrong position because of the driver or their design. Many types of designs were proposed to address this problem. For example, the concept of the WHIPS seat mechanism was developed by the Volvo company (7). This mechanism was designed to reduce cervical injuries caused by rear-end collisions (Figure 2 ). Another design was proposed in which the headrest could swell during an accident (Figure 3) (1).

As the result of much research, it is understood that the distance between the headrest and the head plays a vital role in influencing a whiplash injury $(4,21)$. To reduce the risk of injury, the distance between the headrest and the head must be no greater than $10 \mathrm{~cm}$. Distances of less than $6 \mathrm{~cm}$ enhance safety (21). Unfortunately, headrests that are not adjusted properly and are too far away from the head cannot prevent whiplash injuries.

Another hypothesis suggests that whiplash injuries have increased in number since car seats have been strengthened mechanically (23). The reason that mechanically weaker seats may lead to fewer whiplash injuries is that the angular movement of the head relative to the body is diminished when a seat is broken or stretched backwards with the weight of the driver, as can occur in rear-end collisions (12).

\section{The Mechanism of Whiplash Injuries}

In a normal human's neck, the cervical spine has a lordotic shape. In rear-end collisions, the passenger seat moves towards the impact, and the back part of the seat applies force to the body of the passenger. As the seat pushes-the result of this force-the lower part of the neck moves in the same direction. At the moment of the impact, the lordotic shape of the neck disappears, and the cervical spine straightens.

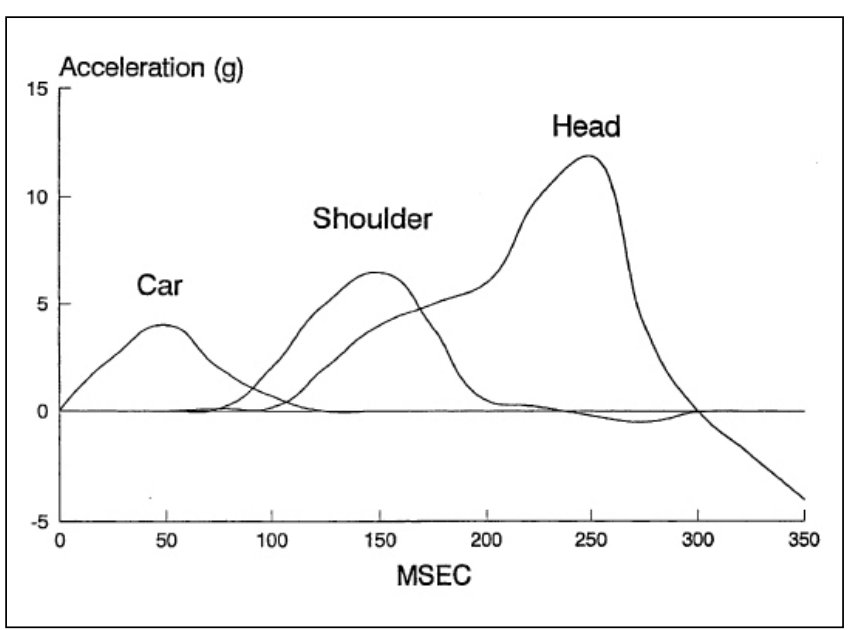

Figure 1: The acceleration of the car, the head and T1 at the average speed of $8 \mathrm{~km} / \mathrm{h}$ (19) (Reprinted with permission).

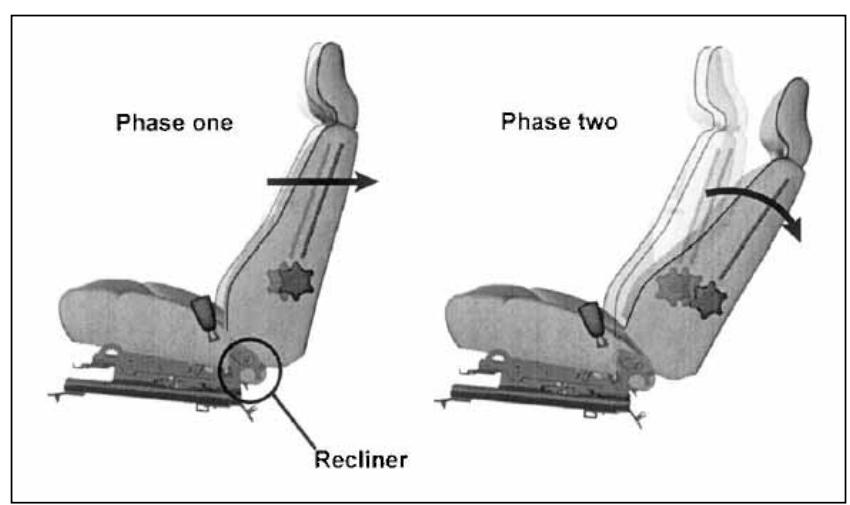

Figure 2: The design of the WHIPS seats (7) (Reprinted with permission).

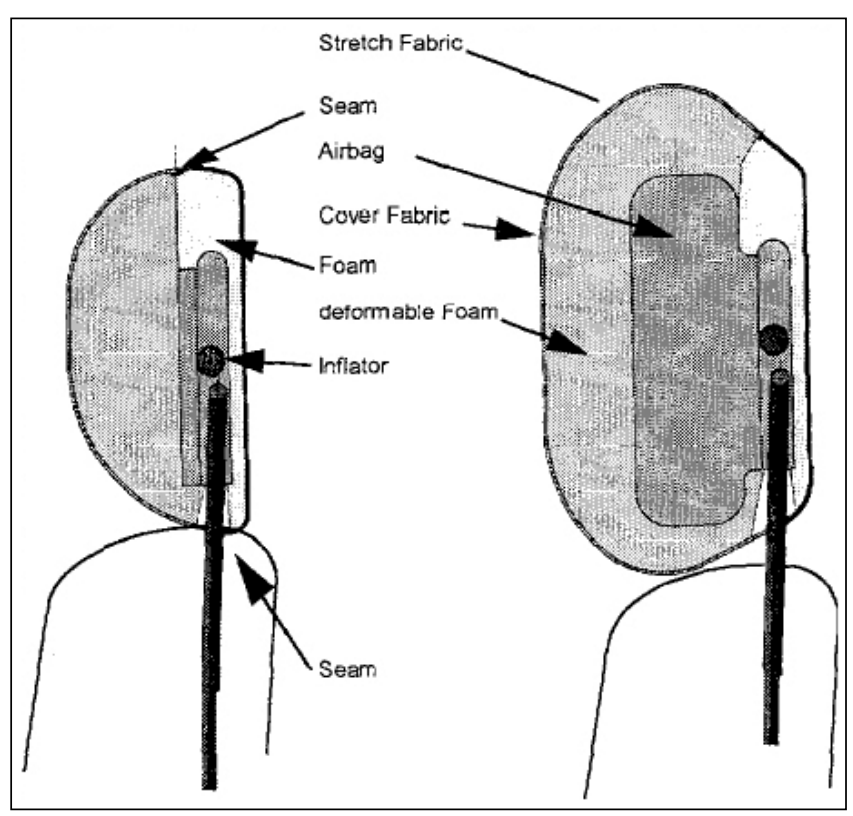

Figure 3: The headrest that can swell during an accident (1) (Reprinted with permission). 
As the body of the passenger continues to be pushed, the head moves backwards, and the extension starts.

In a human cadaver study, Panjabi et al. (14) examined the intervertebral rotation movement for each functional spinal unit at the moment of a whiplash injury (Figure 4). In this study, they suggested that the injury did not actually occur during the hyperextension; instead, there was a more sophisticated mechanism. According to this hypothesis, the head moves backwards directly (without rotation) in the first 50 milliseconds. Between 50 and $75 \mathrm{~ms}$, the cervical spine takes the shape of an "S." In this phase, the upper part of the cervical spine flexes while the lower part extends. The lower parts of the cervical spine and head extend during the periods of $75 \mathrm{~ms}$ and $100 \mathrm{~ms}$, respectively.

According to the hypothesis, whiplash injuries occur when the cervical spine takes the shape of an "S" (6). It can be seen in Figure 5 that the cervical spine becomes an " $S$ " at about 50 $\mathrm{ms}$. When the spine has the shape of an "S," the posterior part of the lower cervical spine is exposed to compression, and the anterior part of the lower cervical spine is exposed to tension. When this situation exceeds the limits of the normal spine, it causes soft tissue injury.

Where does whiplash injury occur? Possible injury sites may include the facet joint tissue, the intervertebral disc, the ligaments, the spinal cord, the muscle and the dorsal nerve

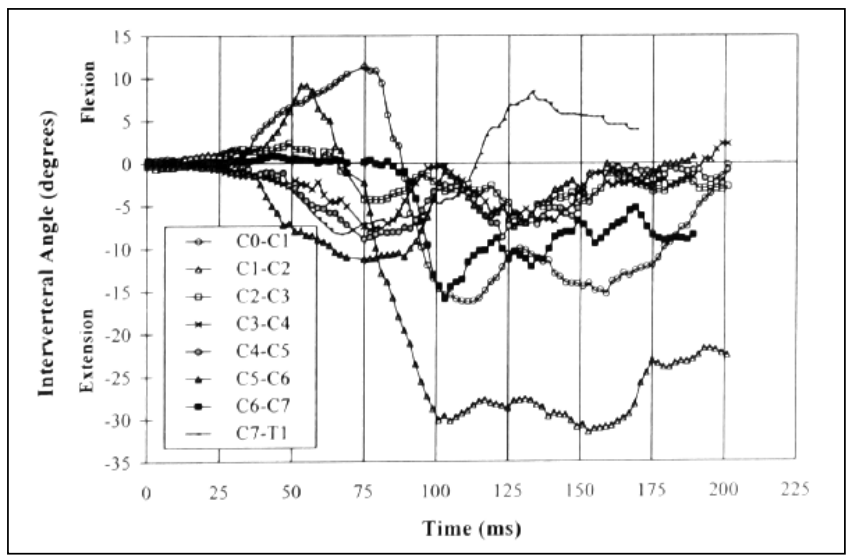

Figure 4: The intervertebral rotation, defined by using highspeed cinematography, in every unit from C0-C1 to C7-T1 that occurs with $8.5 \mathrm{~g}$ acceleration (14) (Reprinted with permission). roots. Many studies have examined the cervical facet capsule specifically for whiplash injury $(8,10,13,16,20,24,25)$. Deng et al. (3) investigated rear impact post mortem human subjects PMHS tests using a high-speed X-ray to analyze spinal motion. They reported that tension in the facet joint tissue emerges before the head touches the headrest. Yoganandan et al. (25) investigated whiplash injuries on human cadavers by analyzing the movements of the facet joints using a highspeed camera. They found that because of the overload that occurs during an accident, different movements occur in the back and front parts of the facet joints in the lower part of the cervical spine. This movement in the facets can be identified as follows: although there was compression in the back part of the facet joint, it was observed to have made a linear gliding movement backwards. It was reported that this excessive movement was the cause of the damage on the facet joint and the whiplash injury (Figure 6).

\section{Whiplash Injury Criteria}

Whiplash injury criteria have been investigated to understand the neck injuries that occur during rear-end car accidents and to develop protective devices to eliminate or minimize the injury. There are several injury criteria.

\section{The Neck Injury Criterion (NIC)}

The NIC criterion is likely the most widely used neck injury assessment to have been proposed. Boström et al. (2) hypothesized that neck injury occurs in the first $100 \mathrm{~ms}$ of a rear impact and is based on relative acceleration and velocity between the head and upper torso. During a rear impact, as the thorax is pushed forward, the lower part of the cervical spine experiences extension, whereas the upper part experiences flexion. A mathematical model was devised to correlate the peak pressure within the spinal column at the point of maximum reaction, which occurs within the first 150 ms of the whiplash trauma. The NIC criterion cannot be used for the entire crash. The calculation of the NIC value is based on the following equation:

$$
\mathrm{NIC}=\mathrm{a}_{\mathrm{rel}}{ }^{*} 0.2+\left(\mathrm{v}_{\mathrm{rel}}\right) 2 \text {, }
$$

where $a_{\text {rel }}$ is the relative acceleration and $v_{\text {rel }}$ is the relative velocity between $\mathrm{C} 1$ and $\mathrm{T} 1$. Injury was thought not to occur if $\mathrm{NIC}<150 \mathrm{~m}^{2} / \mathrm{s}^{2}$.

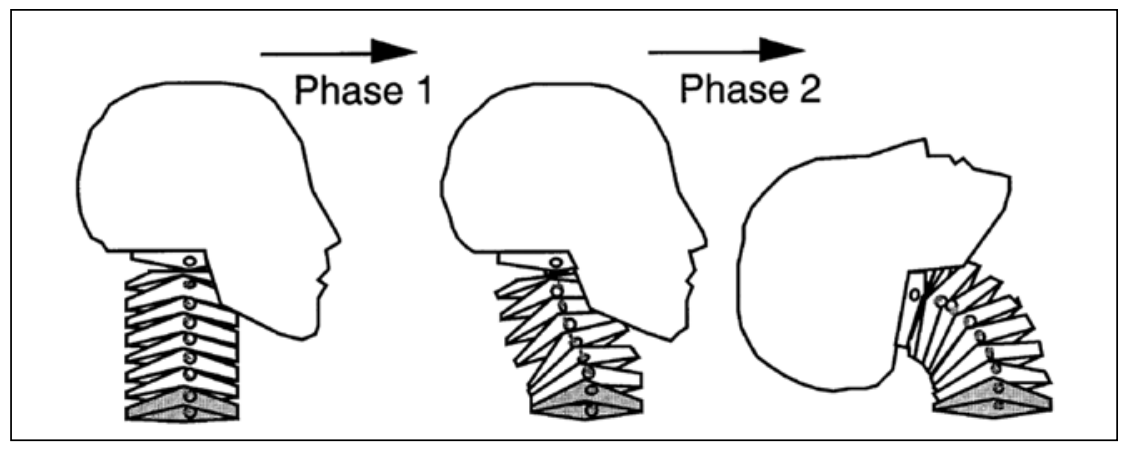

Figure 5: The phases of the mechanism of whiplash injury: Phase1: Reaction. Phase2: Extension (22) (Reprinted with permission). 


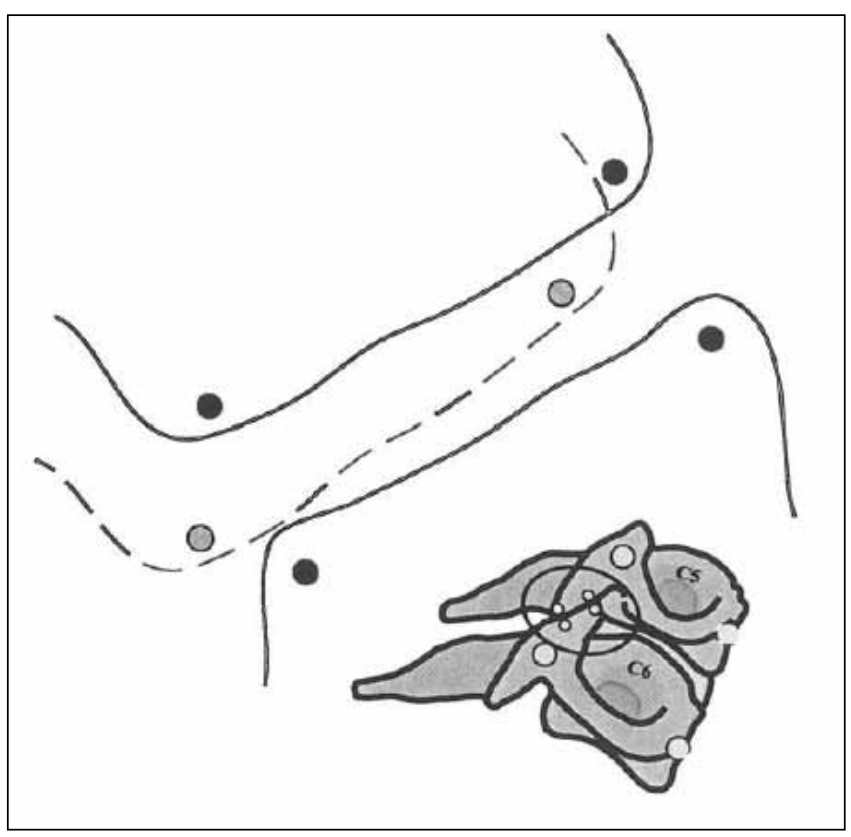

Figure 6: The movement of compression and gliding of the facet joint in the initial phase of the overload. Straight lines represent the facet joint, and the dashed lines represent the movement of upper facet according to the lower facet (25) (Reprinted with permission).

\section{Nij Criterion}

The Nij criterion was proposed to assess neck injuries in frontal impacts involving airbag deployment. The Nij criterion combines the effects of neck loading with the introduction of limits for these loadings at the occipital condyles. These loadings include tension or compression forces and flexion or extension bending moments. The Nij criterion is calculated as follows:

$$
\mathrm{Nij}=\mathrm{Fz} / \text { Fint }+ \text { My/Mint, }
$$

where $\mathrm{Fz}$ is the axial load and $\mathrm{My}$ is the flexion/extension bending moment. Fint and Mint represent critical intercept values for the load and the moment, respectively. These values are used for normalization. Proposed critical intercept values for different dummy sizes have been reported (Eppinger et al). The threshold for injury based on the criterion is 1 .

\section{IV-NIC Criterion}

The IV-NIC is based on the ratio of the extensive intervertebral motion under loading and the physiological range of motion (15). This criterion reflects the hypothesis that surpassing the physiological range of motion may injure soft tissues in the spine. However, this criterion cannot be used for dummy designs due to the limitations placed on dummy intervertebral motion. This criterion is not validated; therefore, no threshold level has been proposed.

\section{Nkm Criterion}

$\mathrm{Nkm}$ is proposed to assess the risk of neck injuries in lowspeed, rear-end collisions. The Nkm criterion is based on shear forces and the bending moment measured at the transition from the head to the neck. It is calculated by the following formula:

$\mathrm{Nkm}=\mathrm{Fx} /$ Fint + My/Mint,

where $\mathrm{Fz}$ is the axial load and $\mathrm{My}$ is the flexion/extension bending moment. Fint and Mint represent critical intercept values for the load and the moment, respectively. A critical threshold value for $\mathrm{Nkm}$ has not yet determined. Schmitt et al. (18) applied the criterion to 40 different seats to show its usefulness.

\section{NDC Criterion}

The proposed criterion is based on the angular and linear displacement responses of the head relative to T1 (23). In this study, OC rotation and $\mathrm{x}$ - and $\mathrm{z}$-displacement with respect to the moving and rotating T1 vertebrae were obtained to determine a response corridor. Four different performance targets (viz., excellent, good, acceptable and poor) were proposed for neck displacements in the Hybrid III and the BioRID P3.

\section{CONCLUSION}

Fifty percent of cervical spine injuries in car accidents occur as the result of rear-end collisions. Biomechanical studies demonstrated that cervical spine undergoes soft tissue injuries during the rear-end collisions. Sigmoid deformation occurs just after the impact in the first 50 milliseconds. In this sigmoid deformation phase, facet joints at the lower cervical exceed normal physiological limits. Posterior part of the facet is exposed to compression and the anterior part of the facet is exposed to tension. Several whiplash injury criteria has been investigated to understand the whiplash injury: NDC criterion, Nkm criterion, V-NIC criterion Nij criterion, NIC criterion.

\section{ACKNOWLEDGEMENTS}

This study was supported in part by the American Hospital in Istanbul and the Surface Science and Technology Center (KUYTAM) of Koc University.

\section{REFERENCES}

1. Bigi D A H, Steffan $H: A$ comparison study of active head restraints for neck protection in rear-end collisions. 16th International Technical Conference on Enhanced Safety of Vehicles 1103-1110, 1998

2. Boström $O$, Svensson $M Y$, Aldman $B$, Hansson $H A$, Ha'land Y, Lo“ vsund P, Seeman T, Suneson A, Sa“ljo“ A, Örtengren T: A new neck injury criterion candidate-based on injury findings in the cervical spinal ganglia after experimental neck extension trauma. Proc. Int. Ircobi Conf. on the Biomechanics of Impact, Dublin, Ireland,1996 
3. Deng B, Begeman PC, Yang KH, Tashman S, King Al: Kinematics of human cadaver cervical spine during low speed rear-end impacts. Stapp Car Crash Journal 44:171-188,2000

4. Farmer CM, Wells JK, Werner JV: Relationship of head restraint positioning to driver neck injury in rear-end crashes. Accident Analysis \& Prevention 31(6):719-728,1999

5. Galasko CSB, Murray PM, Pitcher M, Chambers H, Mansfield S, Madden M, Jordon C, Kinsella A, Hodson M: Neck sprains after road traffic accidents: A modern epidemic. Injury 24(3): 155-157,1993

6. Grauer J N, Panjabi M M, Cholewicki J, Nibu K, Dvorak J: Whiplash produces an s-shaped curvature of the neck with hyperextension at lower levels. Spine 22(21):2489-2494,1997

7. Jakobsson L, Lundell B, Norin H, Isaksson-Hellman I: WHIPS-Volvo's whiplash protection study. Accid Anal Prev 32(2): 307-319,2000

8. Kaneoka K, Ono K, Inami S, Hayashi K: Motion analysis of cervical vertebrae during whiplash loading. Spine 24(8): 763-769,1999

9. Krafft M, Kullgren A, Ydenius A, Tingvall C: Influence of crash pulse characteristics on whiplash associated disorders in rear impacts--crash recording in real life crashes. Traffic Injury Prevention 3(2):141-149, 2002

10. Lu Y, Chen C, Kallakuri S, Patwardhan A, Cavanaugh J M: Neurophysiological and biomechanical characterization of goat cervical facet joint capsules. Journal of Orthopaedic Research 23(4):779-787,2005

11. Lubin S, Sehmer J: Are automobile head restraints used effectively? Can Fam Physician 39:1584-1588,1993

12. O'Neill B, Haddon W, Kelley A B, Sorenson W W: Automobile head restraints--frequency of neck injury claims in relation to the presence of head restraints. American Journal of Public Health 62(3):399-406,1972

13. Panjabi M M, Cholewicki J, Nibu K, Grauer J, Vahldiek M: Capsular ligament stretches during in vitro whiplash simulations. Journal of Spinal Disorders \& Techniques 11(3):227-232,1998

14. Panjabi M M, Cholewicki J, Nibu K, Grauer J N, Babat L B, Dvorak J: Mechanism of whiplash injury. Clin Biomech 13(45): 239-249,1998
15. Panjabi M M, Wang JL, Delson N: Neck injury criterion based on intervertebral motions and its evaluation using an instrumented neck dummy. Proc IRCOBI Conf, Sitges (Spain), 179-190,1999

16. Pearson A M, Ivancic PC, Ito S, Panjabi M M: Facet joint kinematics and injury mechanisms during simulated whiplash. Spine 29(4):390-397,2004

17. Richter M, Otte D, Pohlemann T, Krettek C, Blauth M: Whiplashtype neck distortion in restrained car drivers: Frequency, causes and long-term results. Eur Spine J 9(2):109-117,2000

18. Schmitt KU, Muser MH, Walz FH, Niederer PF: N km --A proposal for a neck protection criterion for low-speed rearend impacts. Traffic Injury Prevention 3(2):117-126,2002

19. Siegmund GP, King DJ, Lawrence JM, Wheeler JB, Brault JR, Smith TA: Head/neck kinematic response of human subjects in low-speed rear-end collisions. Proc 41st Stapp Car Crash Conf, (SAE technical paper 973341), 11:357-385,1997

20. Siegmund G P, Myers B S, Davis M B, Bohnet H F, Winkelstein $B$ A: Mechanical evidence of cervical facet capsule injury during whiplash: A cadaveric study using combined shear, compression, and extension loading. Spine 26(19): 2095-2101,2001

21. Stemper BD, Yoganandan N, Pintar FA: Effect of head restraint backset on head-neck kinematics in whiplash. Accident Analysis \& Prevention 38(2):317-323,2006

22. Svensson MY, Boström O, Davidsson J, Hansson HA, Håland Y. Lövsund $P$, Suneson A, Säljö A: Neck injuries in car collisions - a review covering a possible injury mechanism and the development of a new rear-impact dummy. Accident Analysis \& Prevention 32(2):167-175,2000

23. Viano D C: Seat design principles to reduce neck injuries in rear impacts. Traffic Injury Prevention 9(6):552-560,2008

24. Winkelstein B A, Nightingale R W, Richardson W J, Myers B S: The cervical facet capsule and its role in whiplash injury: $A$ biomechanical investigation. Spine 25(10):1238-1246,2000

25. Yoganandan N, Pintar F A, Cusick J F: Biomechanical analyses of whiplash injuries using an experimental model. Accident Analysis \& Prevention 34(5):663-671,2002 